\section{German Forestry}

By Prof. Franz Heske. Pp. xxv $+342+16$ plates. (New Haven: Yale University Press; London: Oxford University Press, 1938.) 14s. net.

THIS is a large book of 342 pages, and has been chiefly written for the American forester. Dr. Heske deals chiefly with forest economics and policy. The character, extent and ownership of forests in Germany, the growth, production and utilization of wood materials, and the general public services of the forests in the protection of watersheds, in the conservation of wild life, affording recreation and in maintaining industries, employment and stabilizing communities. An interesting fact is stressed. Until recently the management of the forests was under the different German States, with a consequent difference in policy. A greater measure of control of policy by the central Government is now being introduced, a factor which is all to the interests of the country as a whole.

The new departure in such well-established forestry countries as Germany and the former Austria would appear to merit close attention in India, where the devolutionary pendulum has swung so strongly in the contrary direction.

\section{A Bibliography of Eastern Asiatic Botany}

By Elmer D. Merrill and Egbert H. Walker. Pp. xlii +719. (Jamaica Plain, Mass. : Arnold Arboretum of Harvard University, 1938.) 12.50 dollars.

7 HIS magnificent volume, which in truth deserves the hackneyed adjective 'monumental', places all workers on the botany of the Far East in a deep debt of gratitude to the indefatigable authors. The area covered comprises China, Japan, Formosa, Korea, Manchuria, Mongolia, Tibet, eastern and southerm Siberia, and neighbouring regions. The main body of the work consists of an alphabetical index of authors, under whose names the references are arranged chronologically. The scope of each reference is briefly summarized. In addition there are separate general, geographical and systematic indexes, and three appendixes on Oriental bibliography.

The volume contains references up to and including 1936, and appears to be remarkably complete. The authors and sponsors are to be congratulated on the production of a work which will greatly lighten the labour of future research in the flora of eastern Asia.

\section{The Dragonflies of the British Isles}

By Cynthia Longfield. (The Wayside and Woodland Series.) Pp. $220+260$ illustrations. (London and New York : Frederick Warne and Co., Ltd., 1937.) 7s. $6 d$. net.

7 HIS handy manual should prove of material help in popularizing the study of British dragonflies. It is the first to appear on the subject since Lucas's handbook of 1900 , which is expensive and now out of print. Miss Longfield has achieved a judicious blend of scientific accuracy with an absence of all except a very few technicalities, which is what is needed in a work of its kind. It will serve as a guide to the identification of native British species and an introduction to their habits and distribution. Methods of collecting and preserving specimens are described, while a scientific classification of these insects is appended at the end for those who need it. It is up to date, fully illustrated and, in every way, a reliable little volume. We hope that it will arouse more interest in these insects than prevails at present, for there is much spade work, such as their range of distribution in the British Isles, which the amateur might study to advantage.

Mechanics, Molecular Physics, Heat and Sound By Robert Andrews Millikan, Prof. Duane Roller and Prof. Earnest Charles Watson. Pp. xiv $+498+54$ plates. (Boston, New York, Chicago and London : Ginn and Co., 1937.) 4 dollars.

7 HIS text-book, by American authors, seems to be nearly an ideal one for the intermediate science examination of British universities. The style is excellent, and it contains many beautiful plates illustrating the history of physics. It is perhaps particularly valuable for the presentation of mechanics as a branch of physics, with its mathematical side, although not shirked, put in its proper perspective; but the other sections are almost equally good. A student who has used this book will not have to relearn what he already knows in any essentially new way on proceeding to more advanced work.

\section{Höhenstrahlung (Ultrastrahlung)}

Von Dr. Erwin Miehlnickel. (Wissenschaftliche Forschungsberichte, Naturwissenschaftliche Reihe, herausgegeben von Dr. Raphael Ed. Liesegang, Band 44.) Pp. xvi +316. (Dresden und Leipzig : Theodor Steinkopff, 1938.) 23.50 gold marks.

GTUDY of the cosmic radiation has entered on a $\checkmark$ new phase with the recognition of the probable existence of a heavy electron. Dr. Miehlnickel's account of the subject deals with the ground covered prior to this discovery. It is written in the style of Meyer and Schweidler's handbook of radioactivity, and although primarily categorical, is nevertheless full of interest. For a book of this type the illustrations are good, but it would have been improved by more Wilson cloud pictures. The most valuable feature of the book is the classified bibliography interspersed throughout the text.

\section{Bombylliidæ of Palestine}

By E. E. Austen. Pp. ix $+188+4$ plates. (London : British Museum (Natural History), 1937.) $15 s$.

7 HIS monograph is concerned with the rich fauna of Bombyliidæ found in the relatively small country of Palestine. The bulk of the collection upon which it is based was formed by the author during the Palestine campaigns of 1917-18 in the Great War. Out of 128 species or varieties dealt with in its pages no fewer than 46 are described as new. The work is a model of its kind-admirably clear descriptions, first-rate text-figures and excellent printing. It does credit to all concerned in its production. 